\title{
Mortality in a Movie Projectionist Union in Boston, 1910-64
}

\author{
B. G. FERRIS, JR., AND J. WORCESTER \\ From the Departments of Physiology and Biostatistics, Harvard School of Public Health, Boston, Mass., U.S.A.
}

An examination of the mortality experience of the members of a movie projectionist union in the United States has revealed no significant difference between the group that entered prior to 1940 and the group that entered after 1940, nor was their mortality experience greater than that of the general population. It is concluded, therefore, that the possible different levels of exposure of the two groups to the gases and fumes from carbon arcs and to the heat stresses did not contribute significantly to their mortality.

More than 25 years ago concern was expressed regarding the effects of gases and fumes from carbon arcs and of considerable heat stress on the health of movie projectionists (Coltman, 1938; MacQuiddy, Tollman, La Towsky, and Bayliss, 1938a, b; Drinker and Snell, 1938; Downes, 1940). A number of studies at that time concluded that if the lamp housings were adequately ventilated and if the booths were ventilated so that there was no heat stress, then the exposures to the gases and fumes were insignificant. Following these studies, in about 1940, all major cities in the United States passed legislation to ensure adequate ventilation of the housings and the booths.

The recent increase in mortality due to chronic lung disease in the United States reawakened the concern of motion picture operators that there had been significant exposures in the booths. We were asked to determine whether there had been a significant exposure of motion picture operators which could have affected their health. The part of the survey reported here involved the mortality experience of motion picture operators in the Boston area since the inception of the local union.

\section{Methods}

We obtained a list of all persons who had been admitted into the local union branch since it started in I910. The group was divided into those who had entered the union between 1910 and 1939, and those who had entered between 1940 and 1964 . The

Received for publication October 12, 1966 earlier sample represented those men who had been exposed to the materials in the booths at higher levels and for a longer period of time. Since the break occurred at the time of the war it also coincided with a period when no one was taken into the union.

The union, because of the death benefits it pays, had a record of the deaths of members. The death certificates were searched and the cause of death, date of birth, and age at death were tabulated. From the union records, the date of entry into the union was obtained.

From these data it was possible to calculate the person-years at risk (P.Y.A.R.) by age group and for each decade from I9Io to I964. Those persons who came in the year the local union started were credited with one-half year as were all others for their year of joining the union. If a person died in a given year a half-year was counted. The time extended up to December 31, 1964. Members who were still alive on that date contributed a full year at risk. The age-specific person-years at risk by decade were computed. The age-specific mortality rates by decade for New England (Glass, 1964) were used to calculate the expected numbers of deaths for comparison with the observed deaths.

Age-specific death rates for the two groups were calculated. The primary causes of death in the two groups were obtained from the death certificates.

\section{Results}

The local membership, divided into the two groups, is presented in Table I. The average age on entry into the union has been calculated for each 178 
TABLE I

Movie Projectionists, Boston, I910-64

\begin{tabular}{|c|c|c|c|}
\hline & \multicolumn{2}{|c|}{ Entered Union } & \multirow{2}{*}{ Total } \\
\hline & $1910-39$ & $1940-64$ & \\
\hline $\begin{array}{l}\text { Union membership .. } \\
\text { Died since entering union } \\
\text { Average age on entering into } \\
\text { union (yrs) }\end{array}$ & $\begin{array}{c}168 \\
80 \\
\\
29.0 \\
\pm 6.99\end{array}$ & $\begin{array}{c}124 \\
13 \\
38.2 \\
\pm 11.62\end{array}$ & $\begin{array}{r}292 \\
93\end{array}$ \\
\hline
\end{tabular}

group. It is apparent that the average age on entry is markedly lower in the group that entered between I910 and 1939. Deaths in the two groups have probably been well tabulated because of death payments. Entry into the union is also carefully recorded because of seniority rights. Age at entry into the union has been verified either against the birth date from the death certificate or from the birth date given during an interview and administration of a respiratory symptom questionnaire. The ages of a total of 33 persons ( 16 from the early period and 17 from the later period) could not be verified. For these the union records have been accepted.

\section{TABLE II}

Age-Specific Death Rates for Movie Projectionists, BOSTON, I910-64 (PER IOO MAN-YEARS)

\begin{tabular}{|c|c|c|c|c|c|c|}
\hline & \multirow{2}{*}{\multicolumn{4}{|c|}{ Age Group (yrs) }} & \multicolumn{2}{|c|}{ Entered Union } \\
\hline & & & & & \multirow{2}{*}{$\frac{1910-39}{0}$} & \multirow{2}{*}{$\frac{1940-64}{0}$} \\
\hline I5-29 & .. & .. & .. & .. & & \\
\hline $30-39$ & . & .. & .. & .. & 0.148 & 0.229 \\
\hline $40-49$ & $\ldots$ & $\ldots$ & $\ldots$ & . & 0.435 & 0.578 \\
\hline $50-59$ & .. & .. & .. & .. & $1 \cdot 516$ & 0.713 \\
\hline $60-69$ & .. & .. & $\ldots$ & .. & $4 \cdot 244$ & 2.623 \\
\hline $70-79$ & .. & .. & $\ldots$ & .. & 5.689 & 3.509 \\
\hline $80-99$ & . & . & .. & .. & I5.873 & - \\
\hline
\end{tabular}

Age-specific death rates are presented in Table II, expressed per 100 man-years at risk. In general there is not a marked difference between the two groups. In those instances where there are differences the number of deaths is small and there were few persons in the older age groups in the 1940-64 entering category.

If we examine the primary causes of death as listed on the death certificates (Table III), the experiences of the two groups are quite similar and do not show any marked excess of any one category. Admittedly the number of deaths, and especially the number per category for those entering the union after 1940, is small. When the percentage contribution of specific categories to the total is compared with data for the Statistical Abstract of the United States (1962) it can be seen that the percentages are comparable. Respiratory deaths in the 1940-64 group are higher but may reflect the small numbers involved. Although these data have not been age-standardized it is not anticipated that such a procedure would significantly modify these

\section{TABLE IV}

Movie Projectionists, Boston, 1910-64: CoMparison of OBSERVEd aND EXPECTED Deaths

\begin{tabular}{|c|c|c|c|c|}
\hline & & & \multicolumn{2}{|c|}{ Entered Union } \\
\hline & & & $1910-39$ & $1940-64$ \\
\hline $\begin{array}{l}\text { Observed deaths } . . \\
\text { Expected deaths }^{1} \ldots\end{array}$ & $\begin{array}{l}. . \\
.\end{array}$ & $\begin{array}{l}\cdots \\
\cdots\end{array}$ & \multirow{2}{*}{$\begin{array}{l}80 \\
92 \\
0.87\end{array}$} & \multirow{2}{*}{$\begin{array}{l}13 \\
18 \\
0.72\end{array}$} \\
\hline $\begin{array}{lll}\text { SMR } & \ldots & \ldots\end{array}$ & . & .. & & \\
\hline
\end{tabular}

IIn neither entry group is the difference between observed and expected deaths significant at the $I$ in 20 level.

results. Evidence for this is contained in Table IV where the expected and observed numbers of deaths are tabulated. The expected number was deter-

\section{TABLE III}

Causes of Death in a Movie Projectionists' Union, Boston, 1910-64

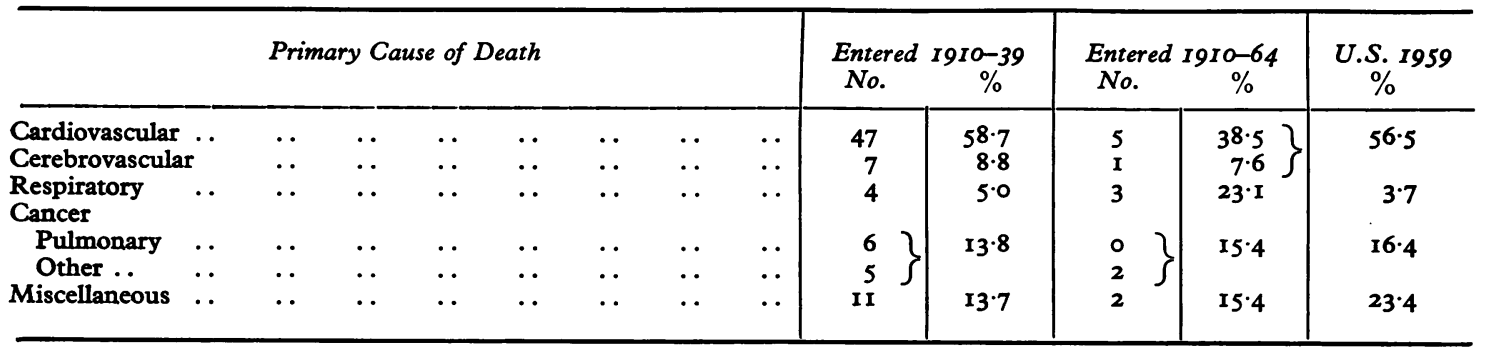




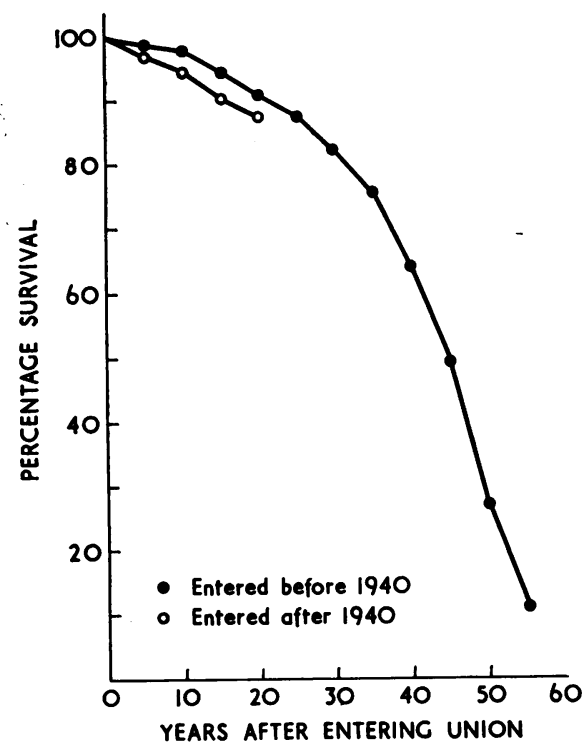

FIGURE. Survival curves for the two groups entering 1910-39 and I940-64.

mined for the PYAR by age and for the various decades from the mortality rates of New England (Glass, I964). In neither category is there a significant difference. In both instances the observed values were lower than those expected from the general population.

A further similarity is shown in the Figure where survival curves following entry into the union have been constructed for the two groups by the method of Merrell and Shulman (1955). The men who entered the union between 1940 and 1964 appear to have a lower probability of survival, despite the fact that they were working in projection booths with much less contamination. Table I probably has the explanation for this in that the average age on entry into the union was about 10 years greater for the 1940-64 group. If the curve were adjusted for this ro-year discrepancy then it would indicate a slightly better probability of survival, which, however, is not likely to be significantly greater.

From these observations it does not appear that the men who had entered the union branch prior to I940 had a higher mortality experience than those who entered after 1940. Exposures prior to 1940 were largely to oxides of nitrogen in the booths. Reported figures (Frederick, quoted by Downes, 1940), were in the range of 0-7.8 p.p.m. Frederick's survey of theatres in Detroit was done about 1939 and is probably representative of projection booths in general at that time in the United States. Those booths with the higher values also had considerable odour of fumes from the arcs. The fumes consisted of various metallic oxides and a few rare earth oxides. None of the fumes attained a significant level in the booths even though the ventilation of the projector was accomplished only by natural convection from the heat of the arc.

The support and co-operation of the following organizations and persons is gratefully acknowledged: Will Rogers Memorial Fund; U.S.P.H.S. Research Grant $\mathrm{OH}-00067$; Local 182 of the International Alliance of Theatrical Stage Employees and Moving Picture Machine Operators of the United States and Canada, American Federation of Labor, Congress of Industrial Organizations; and Mr. Ralph S. Frazier.

\section{REFERENCES}

Coltman, R. W. (1938). F. industr. Hyg., 20, 289.

Downes, A. C. (1940). F. Soc. motion Pict. Engnrs, 35, 32.

Drinker, P., and Snell, J. R. (1938). F. industr. Hyg., 20, 321.

Glass, R. L. (1964). Thesis, H.S.P.H. Mortality of New England Dentists, 192 I-1960.

MacQuiddy, E. L., Tollman, J. P., La Towsky, L. W., and Bayliss, M. (1938a). F. industr. Hyg., 20, 312.

$-, \perp,-$, and - (1938b). Ibid., 20, 297.

Merrell, M., and Shulman, L. E. (1955). F. chron. Dis., I, 12. Statistical Abstract of the United States (1962). 83rd ed. U.S. Dept. of Commerce. 